\title{
Polycythaemia: a clinico-haematological study
}

\author{
Faris Y. Bashir*, Abdul-Kadder S. Ahmed** \\ * Department of Pathology, College of Medicine, University of Mosul; \\ ** Department of Oncology, Oncology and Nuclear Medicine Hospital, Mosul.
}

(Ann. Coll. Med. Mosul 2012; 38 (1): 8-14).

Received: $14^{\text {th }}$ Mar. 2010; Accepted: $5^{\text {th }}$ Jun. 2012.

\begin{abstract}
Objectives: (1) To assess the prevalence of primary and secondary polycythaemia in our locality and their detailed clinical and haematological parameters. (2) To determine causes of secondary polycythaemia. (3) To establish a working formula for determining packed cell volume reduction after a given number of blood units donated.

Methods: A prospective clinico- haematological case series study, done in Mosul teaching hospitals and central blood bank, including seventy two patients with raised packed cell volume. The patients were assessed by clinical evaluation, complete blood picture, coagulation tests, chemical tests, chest $\mathrm{x}$-ray, echocardiography, ultrasound, in addition to arterial $\mathrm{O}_{2}$ saturation and pulmonary function tests. Results: The most common clinical features were headache, dizziness and plethora. The pruritus was present only in polycythaemia vera. Thrombotic complications present more in secondary polycythaemia. Raised packed cell volume and haemoglobin above normal value has been found in all patients. Leucocytosis and thrombocytosis was present in 12/42 patients with polycythaemia vera. Majority of patients with secondary polycythaemia (86.7\%) have ventilatory defects. The effect of number of blood units donated and it's frequency (in weeks) on the degree of packed cell volume reduction in patients treated with venesection was expressed by equations.

Conclusions: Polycythaemia vera patients were younger than those with secondary polycythaemia and found mainly to affect males. All cases of secondary polycythaemia were due either to chronic lung disease or congenital heart disease. We have established an equation when applied to patients with polycythaemia can predict value of packed cell volume reduction after donating a given number of blood units.
\end{abstract}

Keyword: Polycythaemia.

$$
\begin{aligned}
& \text { الخلاصة } \\
& \text { الأهداف: } \\
& \text { ا. ـ در اسة معدل انتثار مرض فرط الكريات الابندائي والثانوي في مجتمعنا والتعرف على تفاصيل العلامات السريرية } \\
& \text { ومقاييس الدم في هذا المرض. } \\
& \text { r. التعرف على الأسباب المؤدية إلى الإصابة بمرض فرط الكابل الكريات الثانوي. }
\end{aligned}
$$

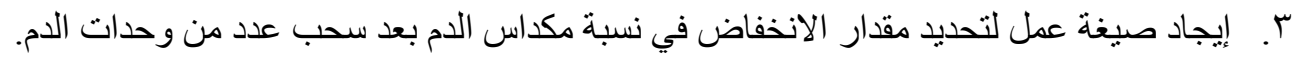

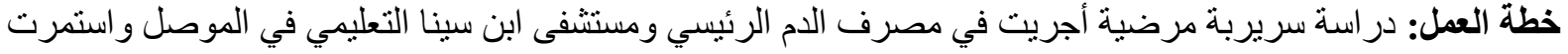

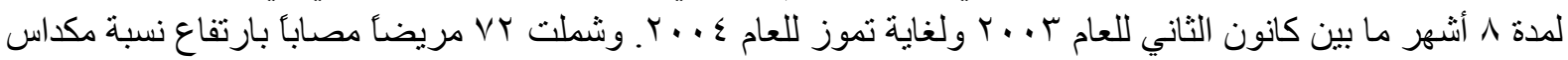

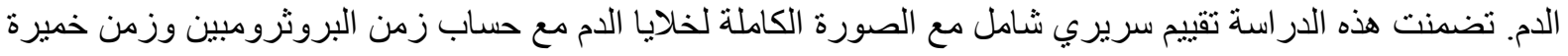


التخثز الجزئية المنشطة، قياس مستوى حامض اليوريك في مصل الدم، أشعة الصدر، فحص إيكو القلب، والفحص

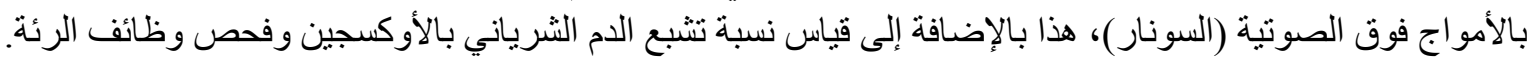

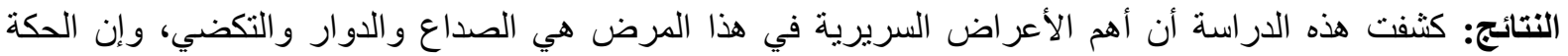

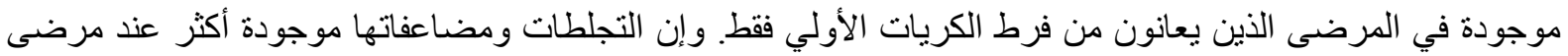

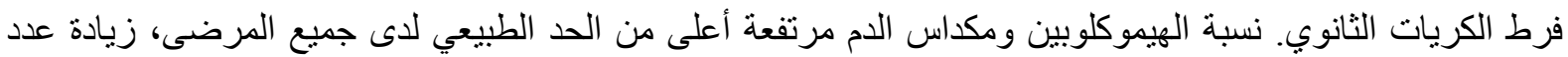

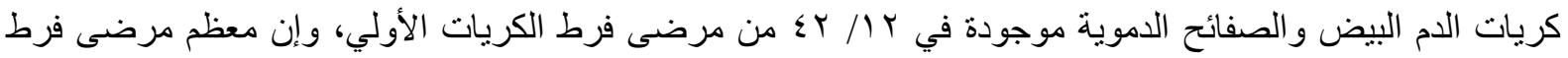

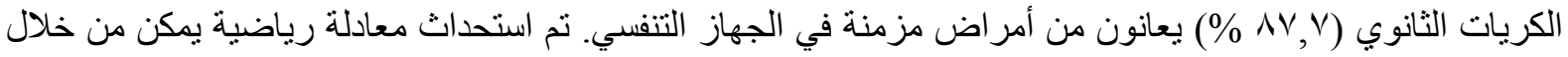

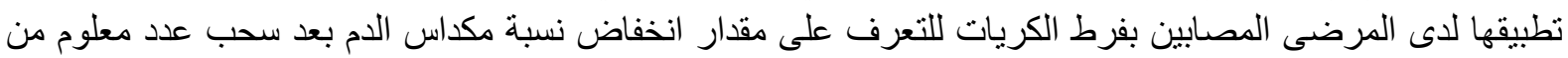
وحدات الدم على مدى فتر ات زمنية (تقاس بالأسابيع). الاستتتاج: مرضى فرط الكريات الابتدائي اصغر سنا من مرضى فرى فرط الكريات الثانوي والذكور أكثر إصابة بالمرض.

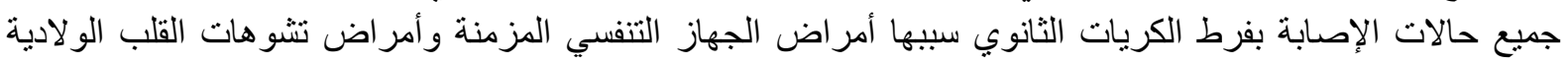
و استحدثت معادلة رياضية يساعد تطبيقها على حساب مقدار انخفاض نسبة مكداس الدم بعد سحب عدد معلوم من وحدات الدم على مدى فترات زمنية.

olycythaemia is defined as a number of conditions characterized by raised packed cell volume; ( $\mathrm{PCV}>0.51 \mathrm{~L} / \mathrm{L}$ in males and $>0.48 \mathrm{~L} / \mathrm{L}$ in females). These conditions may be divided into two groups on the basis of the red cell mass (RCM) findings: ${ }^{(1)}$

I. Absolute polycythaemia. (RCM raised):
A. Polycythaemia vera.
B. Secondary polycythaemia.
C. Idiopathic erythrocytosis.

II. Apparent polycythaemia. (RCM within normal range).

Polycythaemia vera (PV) is a chronic, progressive and ultimately fatal disease, in which the fundamental abnormality is an excessive production of the formed elements of the blood by a hyperplastic bone marrow. The marrow hyperplasia is not secondary to any recognized bone marrow stimulus, and at present the cause is unknown. No increase of plasma erythropoietin has been demonstrated (2). Plasma level of this hormone are reduced in PV patients, and PV progenitor cells, unlike normal ones, can survive in vetro and give rise to erythroid colonies (BFU-E) in the absence of added erythropoietin (endogenous erythroid colonies). ${ }^{(3)}$

In 2005, several groups identified a unique acquired mutation in cytoplasmic tyrosine kinase $\mathrm{JAK}_{2}$ in myeloid cells from the great majority of patients with $\mathrm{PV}^{\left({ }^{(3)}\right.}$
Secondary Polycythaemia is defined as an absolute increase in the red cell mass may arise from a wide variety of causes: ${ }^{(1)}$

1. Polycythaemia secondary to hypoxia:

a) High altitude polycythaemia ${ }^{(4)}$. b) Hypoxaemic lung disease ${ }^{(1,5)}$. c) Cyanotic congenital heart disease ${ }^{(6)}$. d) Smoker's polycythaemia $^{(7)}$. e) Methaemoglobinaemia ${ }^{(1)}$. f) Chemically induced tissue hypoxia ${ }^{(8)}$.

2. Secondary polycythaemia with inappropriate erythropoietin secretion:

a) Renal polycythaemia ${ }^{(9-12)}$. b) Polycythaemia with connective tissue tumours ${ }^{(13)}$. c) Brain tumours $^{(14)}$. d) Hepatoma. e) Endocrine disorder $^{(15)}$. f) Neonatal polycythaemia ${ }^{(16)}$. g) Familial and congenital polycythaemia ${ }^{(17,18)}$.

\section{Patients and methods}

During the period between December 2003 and July 2004, seventy two patients with raised packed cell volume $(\mathrm{PCV}>0.51 \mathrm{~L} / \mathrm{L}$ in males and $>0.48 \mathrm{~L} / \mathrm{L}$ in females), were studied from Mosul teaching hospitals and central blood bank, (61) males and (11) females. Their age ranged between (24-77) years, with a mean age of (50.4) years. After taking history, the patients were examined clinically and haematologically.

Ten $\mathrm{ml}$ of venous blood sample were obtained to perform complete blood picture, coagulation tests (prothrombin time, activated partial thromboplastin time) and chemical 
tests. Arterial Oxygen Saturation $\left(\mathrm{SaO}_{2}\right)$ was done using pulse oximeter (Kontron- 7840), Pulmonary function tests using (Discom-14), chest $x$ ray, abdominal ultrasound were also done. The main diagnostic criteria used in this study were:

A. Raised PCV above $0.51 \mathrm{~L} / \mathrm{L}$ in males and above $0.48 \mathrm{~L} / \mathrm{L}$ in females for diagnosing polycythaemia.

B. Arterial $\mathrm{O}_{2}$ saturation $\left(\mathrm{Sa} \mathrm{O}_{2}\right) \geq 92 \%$ was used to diagnose primary polycythaemia and $\mathrm{Sa} \mathrm{O}_{2}<92 \%$ was used to diagnose secondary hypoxic polycythaemia ${ }^{(1)}$.

\section{Results}

The study included 42 patients diagnosed as $\mathrm{PV}$, the age ranged between (24-77) years, with M:F ratio of 13:1. Thirty cases were diagnosed as secondary polycythaemia, the age ranged between (24-75) years, with M: F ratio of 2.8:1.

In PV $81 \%$ were below 55 years, and only $19 \%$ were equal or above 55 years. In secondary polycythaemia $46.6 \%$ were below 55 years, and $53.4 \%$ were equal or above 55 years.

Clinical features showed headache, dizziness, visual disturbance, plethora and red conjunctiva as the commonest features in most patients. There was statistically significant difference between PV and secondary polycythaemia regarding the following features:

Pruritus was present in $19 \%$ patients with PV while this feature was not present in any patient with secondary polycythaemia $(\mathrm{P}<0.05)$.

Splenomegaly was present in $35.7 \%$ patients with $\mathrm{PV}$ and only in one patient with secondary polycytheamia $(P<0.01)$. There was no significant correlation between Splenomegaly and PCV levels.

Thrombotic complications (Table 1) were present in $11.9 \%$ patients with $\mathrm{PV}$ and in $36.7 \%$ patients with secondary polycytheamia $(P<0.05)$. The risk for thrombosis increase with age from $25 \%$ in patients younger than 55 years to $75 \%$ in those equal or above 55 years (Fig.1), and with increased PCV levels (Fig. 2). Pulmonary function tests showed that the majority of patients with secondary polycytheamia $86.7 \%$ had ventilatory defects compared to $14.3 \%$ in $\mathrm{PV}(\mathrm{P}<0.001)$. Table 2 shows the main causes of secondary polycytheamia.

Haematological findings showed raised PCV above $0.51 \mathrm{~L} / \mathrm{L}$ in males and above $0.48 \mathrm{~L} / \mathrm{L}$ in females were used as main criteria for diagnosing polycythaemia in this study. High $\mathrm{Hb}$ level above normal values has been found in all patients. Leucocytosis and thrombocytosis was present in $12 / 42$ patients with PV. The red cell morphology was normochromic normocytic, few cases were normochromic normocytic/macrocytic. Basophilia was not found in any patients. $80 \%$ of patients presented with ESR levels between $(0-2) \mathrm{mm} / \mathrm{hr}$. PT and APTT were normal in all patients.

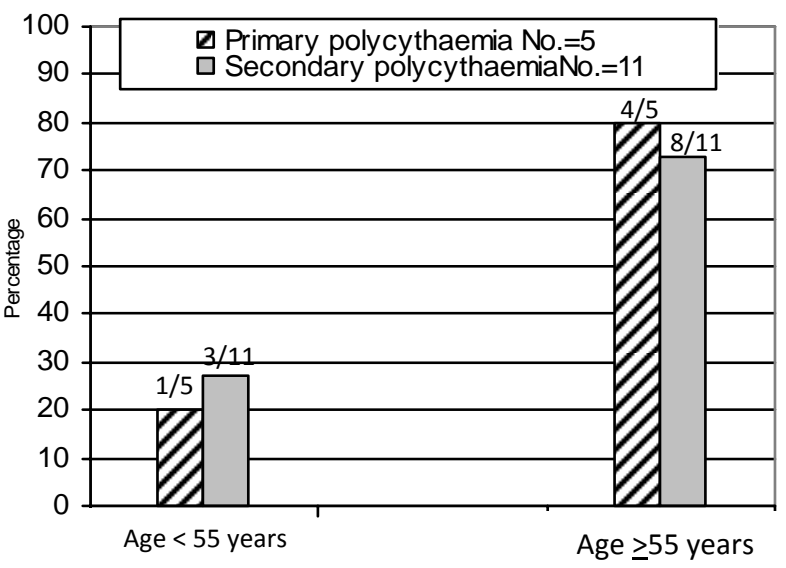

$\mathrm{P}<0.05$

Figure (1): Age and risk for thrombosis in polycythaemia.

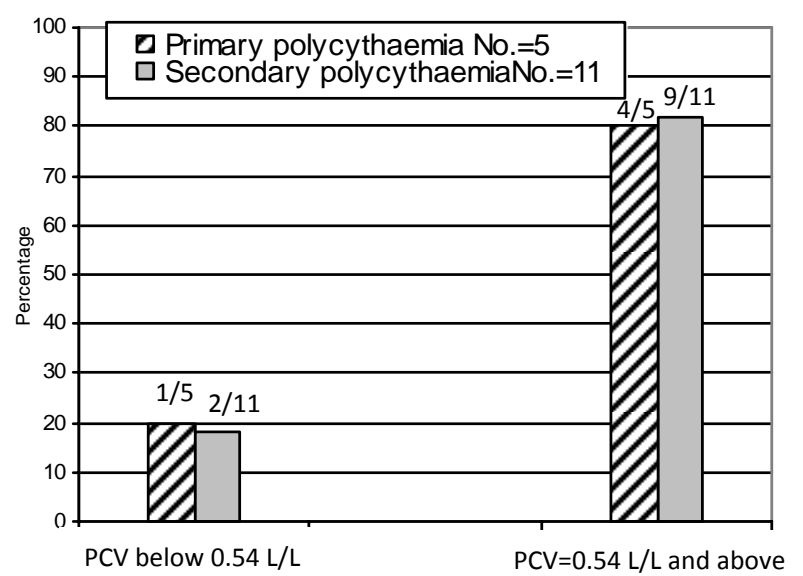

$\mathrm{P}<0.05$.

Figure (2): Thrombotic complications and it's relation to PCV levels in polycythaemia. 
Hyperuriceamia was present in $21 \%$ of patients with $\mathrm{PV}$ and in $37 \%$ of those with secondary polycythaemia, the risk of hyperuriceamia in these patients increased with increasing PCV levels.

The effect of number of blood units donated and its frequency (in weeks) on the degree of $\mathrm{PCV}$ reduction in patients treated with venesection was expressed by the following equations (Table 3,4 ):

A: In patients with primary polycythaemia:

$\mathrm{PCV}$ reduction $\mathrm{L} / \mathrm{L}=0.0496-0.00214$ (weeks)

+0.0248 (No. of blood units donated).

$\mathrm{B}$ : In patients with secondary polycythaemia:

$P C V$ reduction $L / L=0.0034-0.00721$ (weeks) + 0.0538 (No. of blood units donated).

Table (1): Clinical features of the patients.

\begin{tabular}{|c|c|c|c|}
\hline \multirow[t]{2}{*}{ Parameters } & $\begin{array}{c}\text { Primary polycythaemia } \\
\text { Total No. }=(42)\end{array}$ & $\begin{array}{c}\text { Secondary polycythaemia } \\
\text { Total No. }=(30)\end{array}$ & \multirow[t]{2}{*}{ P-value } \\
\hline & No. (\%) & No. (\%) & \\
\hline Headache & $41(97.6)$ & $30(100.0)$ & NS \\
\hline Dizziness & $32(76.2)$ & $24(80.0)$ & NS \\
\hline Visual disturbance & 19(45.2) & $14(46.7)$ & NS \\
\hline Pruritus & $8(19.0)$ & $0(0.0)$ & $<0.05$ \\
\hline Smoking & $21(50.0)$ & $17(56.7)$ & NS \\
\hline Plethora & $37(88.1)$ & $24(80.0)$ & NS \\
\hline Red conjunctiva & $42(100.0)$ & $30(100.0)$ & - \\
\hline Hypertension & $22(52.4)$ & $12(40.0)$ & NS \\
\hline Hepatomegaly & $0(0.0)$ & $4(13.3)$ & $<0.05$ \\
\hline Splenomegaly & $\begin{array}{c}15(35.7) \\
\text { 12/15 palpable. } \\
3 / 15 \text { by U/S only }\end{array}$ & $\begin{array}{l}1(3.3) \\
\text { by U/S only }\end{array}$ & $<0.01$ \\
\hline $\begin{array}{l}\text { Thrombotic } \\
\text { complications }\end{array}$ & $\begin{array}{c}5(11.9) \\
\text { 4/5 CVA } \\
1 / 5 \text { coronary }\end{array}$ & $\begin{array}{c}11(36.7) \\
3 / 11 \text { CVA } \\
8 / 11 \text { coronary }\end{array}$ & $<0.05$ \\
\hline Bleeding tendency & $\begin{array}{c}\text { 4(9.5) } \\
\text { 3/4 Epistaxis } \\
\text { 1/4 Bruises }\end{array}$ & $\begin{array}{c}\text { 2(6.7) } \\
\text { 1/2 Bruises. } \\
\text { 1/2 Haematemesis. }\end{array}$ & NS \\
\hline
\end{tabular}

Table (2): Causes of secondary polycythaemia.

\begin{tabular}{|c|c|}
\hline \multicolumn{2}{|l|}{ Secondary polycythaemia No. $=30$} \\
\hline $\begin{array}{c}\text { Lung disease } \\
\text { No. }=26(86.7 \%)\end{array}$ & $\begin{array}{c}\text { Congenital heart disease } \\
\text { No. }=4(13.3 \%)\end{array}$ \\
\hline $\begin{array}{l}\text { 1. Chronic obstructive airways disease (COAD) No. = } 19(73.1 \%) \\
\text { a: Chronic bronchitis. (14) } \\
\text { b: Bronchial asthma. (4) } \\
\text { c: Bronchiectasis. (1) } \\
\text { 2. *Obesity hypoventilation syndrome No. = } 4(15.4 \%) \\
\text { 3. Fibrosing alveolitis No. = } 2(7.7 \%) \\
\text { 4. Mixed fibrosing alveolitis and obesity hypoventilation syndrome } \\
\text { No. = } 1(3.8 \%)\end{array}$ & $\begin{array}{l}\text { 1. Tetralogy of Fallot: } \\
\text { No. }=2(50.0 \%) \\
\text { 2. Atrial septal defect: } \\
\text { No. }=1(25 \%) \\
\text { 3. Patent ductus arteriosus: } \\
\text { No. }=1(25 \%)\end{array}$ \\
\hline
\end{tabular}

\footnotetext{
* Obesity hypoventilation syndrome:

- (Morbidly obese BMI>40.0 with hypoxaemia) ${ }^{(4)}$.

- BMI (Body mass index)= weight $/$ height $^{2}$ (in $\left.\mathrm{Kg} / \mathrm{m}^{2}\right)^{(4)}$.
} 
Table (3): Effects of No. of blood units donated and the time on PCV reduction in primary polycythaemia.

\begin{tabular}{|c|c|c|c|c|}
\hline \multirow{2}{*}{$\begin{array}{c}\text { No. of blood } \\
\text { units donated }\end{array}$} & \multicolumn{4}{|c|}{ PCV reduction L/L } \\
\cline { 2 - 5 } & $\begin{array}{c}1 \\
\text { week }\end{array}$ & $\begin{array}{c}2 \\
\text { weeks }\end{array}$ & $\begin{array}{c}3 \\
\text { weeks }\end{array}$ & $\begin{array}{c}4 \\
\text { weeks }\end{array}$ \\
\hline 1 & 0.072 & & & \\
\hline 2 & 0.097 & 0.095 & 0.093 & 0.091 \\
\hline 3 & 0.121 & 0.119 & 0.117 & 0.115 \\
\hline 4 & 0.146 & 0.144 & 0.142 & 0.140 \\
\hline
\end{tabular}

The above data was obtained from the equation: $\mathrm{PCV}$ reduction $\mathrm{L} / \mathrm{L}=0.0496-0.00214$ (weeks) + 0.0248 (No. of blood units donated).

Table (4): Effects of No. of blood units donated and the time on PCV reduction in secondary polycythaemia.

\begin{tabular}{|c|c|c|c|c|}
\hline \multirow{2}{*}{$\begin{array}{c}\text { No. of blood } \\
\text { units donated }\end{array}$} & \multicolumn{4}{|c|}{ PCV reduction L/L } \\
\cline { 2 - 5 } & $\begin{array}{c}1 \\
\text { week }\end{array}$ & $\begin{array}{c}2 \\
\text { weeks }\end{array}$ & $\begin{array}{c}3 \\
\text { weeks }\end{array}$ & $\begin{array}{c}4 \\
\text { weeks }\end{array}$ \\
\hline 1 & 0.05 & & & \\
\hline 2 & 0.103 & 0.096 & 0.089 & 0.082 \\
\hline 3 & 0.157 & 0.150 & 0.143 & 0.135 \\
\hline 4 & 0.211 & 0.204 & 0.197 & 0.189 \\
\hline
\end{tabular}

The above data was obtained from the equation: $\mathrm{PCV}$ reduction $\mathrm{L} / \mathrm{L}=0.0034-0.00721$ (weeks) + 0.0538 (No. of blood units donated).

\section{Discussion}

In PV the age ranged between (24-77) years with a mean of 48 years. This is quite expected as $\mathrm{PV}$ is a disease of the middle and later years of life, with a wide range of distribution from adolescence to old age ${ }^{(19)}$. Sex distribution showed male to female ratio of 13:1, this result shows very high male predominance which does not agree with that reported in other studies which reported that males are affected slightly more frequently than females ${ }^{(1,19,20)}$. The increased prevalence of PV among males in the present study may be attributed to small sample size, short period of study and more frequent PCV checking among males than females particularly before blood donation in central blood bank which may reveal subclinical form of the disease in males.

In secondary polycythaemia the age ranged between (24-75) years with a mean of 54 years. This was expected as the main cause of secondary polycythaemia in this study was chronic obstructive airway disease (COAD) which manifests itself in late adult life ${ }^{(21)}$. Sex distribution showed male predominance with $\mathrm{M}: \mathrm{F}$ ratio of 2.8:1, and this is also expected as the majority of COAD patients are smokers ${ }^{(21)}$, and cigarette smokers in the present study were only seen in males.

The main clinical features in PV patients in the present study were: headache, dizziness, plethoric facies, red conjunctiva, visual disturbance, hypertension, splenomegaly and pruritus. Some cases present with thrombotic complications and bleeding tendency. These features are in conformity with that of wellknown reports ${ }^{(1,19)}$.

Pruritus was only found in PV and absent in secondary polycythaemia. This may support the fact that pruritus is attributed to increased histamine release by granulocytes ${ }^{(1,8)}$.

Splenomegaly was not related to increased PCV levels. This may indicate that splenic enlargement in PV was not due to expanded blood volume, this result agrees with that of other studies ${ }^{(19)}$.

A statistically significant higher percentage of thrombosis $36.7 \%$ has been found in our secondary polycythaemic patients. This may be attributed to the age of the studied patients as the risk for thrombosis increases with age $^{(20)}$. Figure 4 may indicate that aggressive treatment of polycythaemia in high risk patients would be associated with a reduced risk for thrombosis.

Hepatomegaly has been reported in $\mathrm{PV}^{(22)}$. In the present study it was not reported and this may be attributed to small sample size included in this study. Four cases with secondary polycythaemia presented with hepatomegaly and this may be attributed to COAD associated with cor pulmonale (congestive Hepatomegaly) ${ }^{(23)}$. 
Bleeding and bruises are reported in $9.5 \%$ of PV patients, higher percentage $25 \%$ was reported in other studies ${ }^{(24)}$.

The present study demonstrates that chronic lung disease and congenital heart disease are the only causes for secondary polycythaemia. This finding agrees with the result of most works in this field of study which reported that the great majority of cases of secondary polycythaemia are due to a disorder which causes a lowering of the arterial oxygen saturation of the blood (Hypoxic secondary polycythaemia).

The majority of our secondary polycythaemic cases showed ventilatory defect, this was expected as the main cause of secondary polycythaemia in the present study was found to be lung disease (Table 2). These results agree with other studies which reported that hypoxia caused by COAD is one of the most common causes of secondary polycythaemia (25)

High $\mathrm{Hb}$ level above normal values has been found in all patients, this is quite expected as all patients included in this study were polycythaemic. Thrombocytosis and leucocytosis were the main findings in PV patients included in this study(12/42), higher percentage has been reported in most of other studies $^{(1,8,25)}$. A statistically significant difference has been found between PV and secondary polycythaemia regarding these two parameters and this is expected as $\mathrm{PV}$ is a panmyelosis and there is over production of granulocytes and platelets ${ }^{(25)}$.

The red cell morphology in the present study was normal with occasional macrocytosis. Similar observation was noticed by other studies $^{(1,2)}$. Basophilia was not reported in any of the studied patients, and this does not agree with the result of most other studies which showed that peripheral blood basophile numbers may be modestly increased in $\mathrm{PV}^{(1,25)}$. This may be attributed to small sample size, or unique feature of our studied patients. ESR levels in the majority of the studied patients was low ranging from $0-2 \mathrm{~mm} / \mathrm{hr}$. PT and APTT are normal in all studied patients. These result are in accordance with most other studies $^{(1,2,8)}$.
In PV 21\% patients present with hyperuricaemia. This was expected as there was excessive cellular proliferation in this disease result in increased synthesis and degeneration of nucleoprotein and production of increased amount of uric acid ${ }^{(19)}$.

In secondary polycythaemia $37 \%$ patients present with hyperuricaemia and this may suggest a causative role of medication used especially diuretics and low dose aspirin ${ }^{(26,27)}$. These two drugs are used by large proportion of our patients in combination with other antihypertensive drugs as $40 \%$ of our secondary polycythaemic patients are hypertension.

\section{Conclusions}

1. Polycythaemia vera (PV) patients were younger than those with secondary polycythaemia. PV was found mainly to affect males.

2. Risk for thrombosis in both types of polycythaemia increases with age and with increasing PCV level.

3. All cases of secondary polycythaemia were due to either chronic lung disease or congenital heart disease with low arterial oxygen saturation.

4. Thrombocytosis and leucocytosis were the main haematological abnormalities in PV. Basophilia was not seen in all cases, PT and APTT were normal in all cases.

5. Hyperuricaemia was more frequent among patients with PCV levels equal or above $0.54 \mathrm{~L} / \mathrm{L}$.

6. Venesection was the best method for treatment in both groups of polycythaemia.

7. We have established an equation when applied to patients with polycythaemia can predict PCV reduction values after donaing a given number of blood units.

\section{References}

1. Hoffbrand AV, Lewis SM, Tuddenham EGD. Postgraduate haematology. $4^{\text {th }} \mathrm{ed}$. Butterworth Heinmann; 1999. p. 404-516.

2. DeGruchy GC. Clinical haematology in medical practice. $4^{\text {th }}$ ed. CBS publisher and Distributor; 1984. p.556,563-565, 582. 
3. Hoffbrand AV, Catovsky D, Tuddenham EGD, et al. Postgraduate haematology. $6^{\text {th }}$ ed. Wiley - Blackwell; 2011. p. 687.

4. Ganong WF. Review of medical physiology. $7^{\text {th }}$ ed. Lange medical publications; 1975. p. 505-506.

5. Vlahakos DV, Kosmas EN, Dimopoulou I, et al. Association between activation of renin-angiotensin system and secondary erythrocytosis in patient with chronic obstructive pulmonary disease. Am J Med 1999; 106: 158-164.

6. Vongpatanasin W, Brickner E, Hillis LD, et al. The Eisenmenger syndrome in adults. Ann Int Med 1998; 128: 745-755.

7. Smith JR, Landaw SA, Smoker's polycythaemia. N Engl J Med 1978; 298: 6-10.

8. Beutlers E, Coller BS, Lichtman MA, et al. Williams Haematology. $6^{\text {th }}$ ed. McGrawHill Medical Publishing Division; 2001. p. 689-698.

9. Bailey RR, Shand $\mathrm{BI}$, walker RJ. Reversible erythrocytosis in a patient with hydronephrotic horseshoe kidney. Nephron 1995; 70: 104-105.

10. Sakamoto S, Igarashi T, Osumi N, et al. Erythropoietic producing renal cell carcinoma in chronic haemodialysis patients: A report of 2 cases. Int J Urology 2003; 10: 49.

11. Vlahakos DV, Marathias KP, Agroyannis $\mathrm{B}$, et al. Post transplant erythrocytosis. Kidney Int 2003; 63: 1187.

12. Kurella M, Butterly DW, Smith SR. Post transplants erythrocytosis in hypercalcaemic renal transplant recipients. Am J Transplant 2003; 3: 873-877.

13. LevGur M, Levie MD. The myomatous erythrocytosis syndrome: a review. Obstetric and Gynecology 1995; 86: 10261030.

14. Trimble M, Caro J, Tallala A, et al. Secondary erythrocytosis due to cerebellar haemangioblastoma: demostration of erythropoietin in mRNA in the tumour. Blood 1991; 78: 599-601.
15. Shulkin BL, Shapiro B, Sisson JC. Pheochromocytoma, polycythaemia and venous thrombosis. Am J Med 1987; 83: 773-776.

16. Wiswell TE, Cornish JD, Northam RS. Neonatal polycythaemia: Frequency of clinical manifestations and other association findings. Pediatrics 1986; 78 : 26-29.

17. Kralovics R, Indrak K, Stopka T, et al. Two new erythropoietin receptor mutation: Truncated EPO receptor are most frequently associated with primary familial and congenital polycythaemia. Blood 1997; 90: 2057-2061.

18. Motohashi T, Nakamura $\mathrm{Y}$, Osawa $\mathrm{M}$, et al. Increased cell surface expression of Ctermianl truncated erythropoietin receptor in polycythaemia. Eur J Haematol 2001; 67: 88.

19. Williams WJ, Beutlers E, Erslev AJ, et al. Haematology. $3^{\text {rd }}$ ed. McGraw-Hillbook; 1983. p. 185-191, 676.

20. Policitemia, GIS. Polycythaemia vera: the natural history of 1213 patients followed for 20 years. Ann Inter Med 1998; 123:656-664.

21. Gibson GJ, Geddes DM, Costabel U, et al. Respiratory medicine. $3^{\text {rd }}$ ed. Saunders; 2003. p. 1112-1113.

22. Hughes-Jones NC, Wickramasinghe SN, Hatton C. Lecture notes on Haematology. $7^{\text {th }}$ ed. Blackwell Publishing; 2004. p. 148.

23. Lane DJ. Respiratory disease. $3^{\text {rd }}$ ed. Heinemann; 1976. p. 316.

24. Lichtman MA, Beulter E, Kipps TJ, et al. Manual of Haematology. $6^{\text {th }}$ ed. McGrawHill; 2003. p. 165.

25. Hoffbrand AV, Pettit JE, Moss PAH. Essential haematology. $4^{\text {th }}$ ed. Blackwell Science; 2001. p. 227-229, 232.

26. Tirney LM, Mcphee SJ, Papadakis MA. Current Medical Diagnosis and Treatment. $42^{\text {nd }}$ ed. McGraw-Hill; 2003. p. 787.

27. Andreoli TE, Carpenter CCJ, Griggs RC, et al. Cecil Essentials of Medicine. $5^{\text {th }}$ ed. W.B. Saunders; 2001. p. 708. 